\title{
$\mathrm{ICM}$ Indonesian Journal of
}

e-ISSN : 2598-9421

\section{Model Sistem Pakar Fuzzy Logic Method untuk Menentukan Status Akreditasi pada Sistem Informasi SAPTI Universitas Kristen Satya Wacana Berbasis Web}

\author{
Bintang Lazuardi ${ }^{1)}$, Sri Yulianto Joko Prasetyo*2) \\ ${ }^{1,2)}$ Fakultas Teknologi Informasi, Program Studi Teknik Informatika Universitas Kristen Satya Wacana
}

\begin{abstract}
Tujuan dari penelitian ini adalah menerapkan metode sistem pakar Fuzzy Logic Method pada Sistem Akreditasi Program Studi Internal (SAPTI) Universitas Kristen Satya Wacana berbasis teknologi web. Metode tersebut digunakan untuk menentukan status akreditasi pada setiap program studi yang direpresentasikan dalam bahasa pemrograman PHP, MySQL, Javascript, dan HTML. Status akreditasi ditentukan berdasarkan aturan-aturan variabel penentu. Selanjutnya dimasukkan kedalam basis pengetahuan sistem pakar dan dilakukan perhitungan secara matematis dengan menggunakan metode inferensi fuzzy Tsukamoto. Berdasarkan tahapan tersebut menghasilkan status akreditasi dengan beberapa kategori rentang nilai yaitu 0\%-70\% merupakan status gagal akreditasi, $70 \%-82.5 \%$ revisi akreditasi, dan $82.5 \%-100 \%$ sukses akreditasi.
\end{abstract}

Keyword - Fuzzy Logic Method, sistem pakar, sistem inferensi fuzzy Tsukamoto, status akreditasi

\section{PENDAHULUAN}

$\mathrm{N}_{\mathrm{m}}$ APTI (Sistem Akreditasi Program Studi Internal) merupakan sistem informasi yang digunakan untuk melakukan akreditasi internal pada setiap program studi yang terdaftar di UKSW. Setiap program studi memiliki status akreditasi berbeda sesuai dengan yang ditetapkan oleh Badan Akreditasi Nasional Perguruan Tinggi (BA6N-PT). Sesuai dengan data BAN-PT pada tahun 2018 terdapat 57 program studi UKSW yang telah terdaftar dan masuk kedalam daftar masa akreditasi [1]. Dengan banyaknya program studi yang terdaftar tersebut, maka akan muncul permasalahan status akreditasi pada sistem informasi SAPTI berupa penumpukan status akreditasi dan pengelolaan status akreditasi yang belum di manajemen dengan baik dan tepat.

Maka dari itu diperlukan suatu penelitian guna memecahkan permasalahan tersebut. Dengan menerapkan sistem pakar dan Fuzzy Logic Method pada sistem informasi SAPTI diharapkan status akreditasi pada setiap program studi dapat dimanajemen dengan baik dan tepat sehingga meminimalisisr terjadinya penumpukan dan status akreditasi yang ambigu.

Penelitian ini menerapkan pengatahuan sistem pakar dan metode Fuzzy Logic. Sistem penjadwalan adalah pembagian waktu berdasarkan rencana pengaturan urutan kerja yang saling berhubungan dan berinteraksi dalam satu kesatuan untuk menjalankan proses pencapaian suatu tujuan utama [2]. Sistem pakar adalah sebuah sistem yang berusaha mengadopsi kepakaran atau keahlian suatu bidang keilmuan tertentu yang dimiliki oleh pakar dam memasukkannya kedalam sebuah komputer yang nantinya akan menghasilkan suatu penyelesaian permasalahan [3]. Dengan metode tersebut, diharapkan sistem implementasi pada status akreditasi sistem informasi SAPTI akan dimanajemen dengan baik dan tepat. Sehingga informasi yang disampaikan mudah dipahami dan dimengerti pengguna sistem informasi SAPTI.
Penelitian ini lebih berfokus pada kolaborasi pengetahuan sistem pakar yakni sistem pakar dan Fuzzy Logic Method, dengan tujuan bahwa sistem informasi SAPTI ini memiliki status penjadwalan yang berdasarkan sistem kepakaran.

\section{TINJAUAN PUSTAKA}

\subsection{Penelitian Terdahulu}

Penelitian yang berjudul Penerapan Logika Fuzzy Dalam Penjadwalan Waktu Kuliah [4], penelitian ini membahas tentang penjadwalan dalam suatu perguruan tinggi yang harus dilakukan dengan baik sehingga tidak menimbulkan penjadwalan kuliah yang rancu dan tumpang tindih antar mata kuliah satu dengan matakuliah lainnya. Penelitian ini menerapkan metode logika fuzzy untuk mengatur sistem penjadwalan tersebut dengan berfokus pada penggunaan sistem inferensi fuzzy. Hasil dari penelitian ini adalah peningkatan rata-rata nilai akurasi sebesar $90.12 \%$ metode mamdani dan nilai akurasi sebesar $70.63 \%$ metode sugeno dengan rata-rata selisih nilai sebesar $19.50 \%$.

Penelitian selanjutnya adalah penelitian yang berjudul Penjadwalan Perkuliahan Otomatis Berbasis Fuzzy Logic dan Genetic Algorithm Pada Universitas Dian Nuswantoro [5]. Penelitian ini membahas tentang perancangan dan pengembangan sistem penjadwalan otomatis dengan menggunakan algoritma genetika dan dioptimasi dengan fuzzy logic untuk mempercepat proses penjadwalan. Fuzzy logic dipilih untuk dikombinasikan dengan algoritma genetika guna mendapatkan performance, aturan fuzzy logic yang diterapkan menjadi lebih praktis. Hasil dari eksprerimen yang telah dilakukan dengan melakukan simulasi penjadwalan, bahwa dengan setting parameter genetika 40 kromoson, crossover rate $10 \%$ dan mutation rate sebesar $10 \%$ dihasilkan global optimum yang rata-rata dicapai pada generasi ke 18 dengan waktu komputasi sebanyak 267 detik 
atau 4.45 menit. Sehingga dengan menambahkan fuzzy logic pada algoritma genetika terbukti bahwa proses penjadwalan perkuliahan secara otomatis menjadi lebih optimal.

Penelitian selanjutnya adalah penelitian yang berjudul Pengembangan Aplikasi Penjadwalan Pasien-Dokter Berbasis Logika Samar (Fuzzy Logic) dan Algoritma Genetika (Genetic Algorithm) [6]. Penelitian ini membahas bagaimana menerapkan logika samar (fuzzy logic) dan algoritma genetika (genetic algorithm) untuk mengembangkan aplikasi penjadwalan pasien-dokter sehingga bisa dihasilkan antrian yang efektif dan efisien bagi semua entitas yang terlibat. Fuzzy Logic merupakan sebuah metode penyelesaian masalah yang bisa digunakan untuk menyelesaikan masalah-masalah yang mengandung ketidakpastian atau samar-samar. Dalam penelitian ini masalah ketidakpastian tersebut adalah antrian pasien yang belum efektif dan efisien. Fuzzy Logic digunakan sebagai sebuah preprocessing dari beberapa input data pasien yang ada. Data input akan diubah menjadi data baru yang berguna untuk perhitungan dalam proses utama. Untuk proses utama digunakan Genetic Algorithm yang berperan sebagai penerima input data pasien dan penerima output data Fuzzy Logic untuk diproses menjadi sebuah hasil akhir yang berupa antrian pasien. Berdasarkan hasil implementasi dan analisa pengujian didapatkan kesimpulan akhir dimana Fuzzy Logic dan Genetic Algorithm dapat diterapkan dalam membangun aplikasi penjadwalan pasien-dokter dalam menghasilkan antrien pasien yang efektif, Fuzzy Logic dan Genetic Algorithm memiliki hasil optimasi setiap entitas yang lebih baik dibandingkan dengan antrian konvensional first come first serve.

\subsection{Landasan Teori}

\subsubsection{Sistem Pakar}

Sistem pakar salah satu bidang kecerdasan buatan (artificial intelligence) yang didefinisikan sebagai sebuah program komputer yang dirancang untuk mengambil keputusan seperti sebuah keputusan halnya seorang pakar ahli, dimana dalam mengambil keputusan tersebut digunakan pengetahuan (knowledge base), fakta dan teknik berfikir dalam menyelesaikan masalah-masalah yang biasanya hanya dapat diselesaikan oleh seorang pakar [7].

Dalam pengembangan suatu sistem pakar, pengetahuan (knowledge base) berasal dari seorang ahli atau merupakan pengetahuan yang diambil dari media seperti majalah, buku, jurnal, dan yang lain. Kemudian dalam sistem pakar pengetahuan bersifat khusus hanya untuk satu domain masalah khusus tertentu saja. Semakin banyak sumber ilmu pengetahuan yang dimasukkan kedalam sistem pakar maka akan semakin baik dalam bertindak dan mengambil solusi sehingga hamper menyerupai pakar sebenarnya [8].

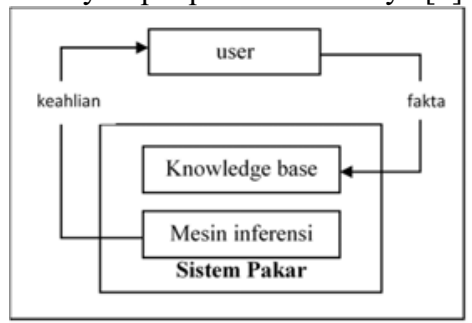

Gambar 1. Konsep Dasar Sistem Pakar (sumber: Arhami, 2005)
Gambar 1 diatas merupakan konsep dasar sistem pakar, dimana user menyampaikan infomrasi berdasarkan fakta yang sebenarnya kepada sistem pakar, kemudian informasi tersebut akan dimasukkan kedalam basis knowledge base dan diolah dengan mesin inferensi (mekanisme inferensi), sehingga sistem akan memebrikan respon berupa keahlian atau jawaban berdasarkan pengetahuan yang dimilikinya [9].

Tujuan dari sistem pakar adalah mentransfer kepakaran yang dimiliki seorang pakar kedalam sebuah komputer dan kemudian adalah [10] :

1.) Knowledge Acquisition (dari pakar atau sumber lain).

2.) Knowledge Representation (kedalam kompuer).

3.) Knowledge Inferencing (lakukan inferensi pengetahuan).

4.) Knowledge Transferring (pengalihan pengetahuan ke user).

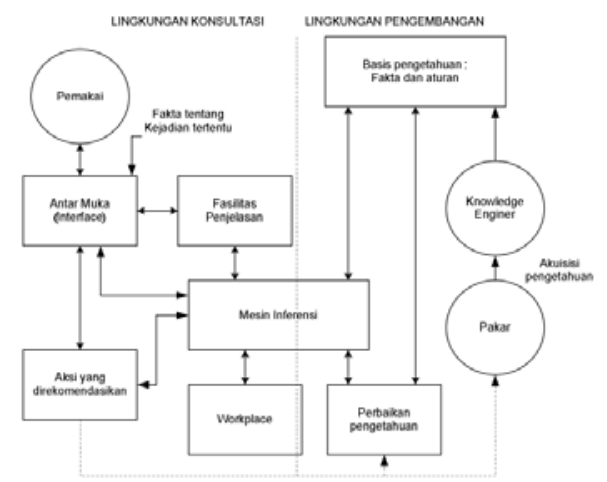

Gambar 2. Arsitektur Sistem Pakar (sumber: Turban, 1995)

Gambar 2 merupakan gambar arsitektur sistem pakar. Komponen-komponen yang terdapat pada arsitektur sistem pakar tersebut terdiri dari antarmuka pemakai, basis pengetahuan : fakta dan aturan, akuisisi pengetahuan, mekanisme inferensi, workplace, fasilitas penjelasan, perbaikan pengetahuan [11].

Basis Pengetahuan adalah bagian dari sebuah sistem pakar yang menyimpan pengetahuan (domain knowledge). Basis pengetahuan yang terkandung dalam sistem pakar berbeda antara satu dengan yang lainnya, tergantung dari bidang kepakaran sistem yang dibangun.

Inference engine bertugas mencari padanan antara fakta yang ada didalam working memory dengan fakta-fakta tentang domain knowledge tertentu yang adal didalam basis pengetahuan, selanjutnya inference engine akan menarik / mengambil kesimpulan dari masalah yang diajukan kepada sistem.

Antarmuka pemakai memberikan fasilitas komunikasi antara pemakai dan sistem, memberikan berbagai fasilitas informasi dan berbagai keterangan yang bertujuan untuk diarahkan alur penelusuran masalah sampai ditemukan solusi.

Akuisisi pengetahuan adalah proses untuk mengumpulkan data pengetahuan dari sumber pengetahuan (berasal dari pakar sebenarnya atau media) kedalam komputer.

Aturan Basis Pengetahuan 
Perancangan aturan melibatkan keterkaitan atau hubungan antara manifestasi dengan kategori penjadwalan sesuai dengan ilmu kepakaran yang telah dimasukkan basis pengetahuan.

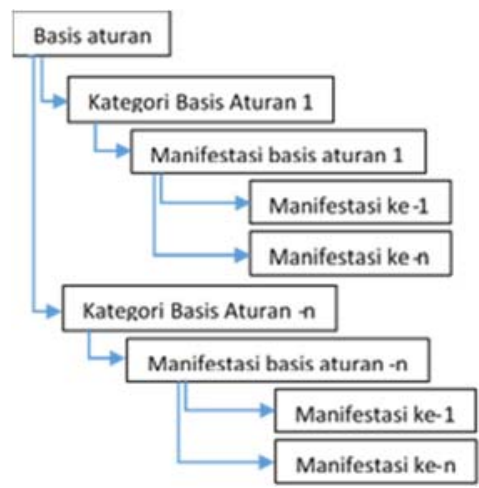

Gambar 3. Aturan Basis Pengetahuan (sumber: Arhami, 2005)

Pada gambar 3 dijelaskan bahwa aturan-aturan dimasukkan kedalam basis aturan sesuai dengan jumlah kategori yang ada, kemudian dikumpulkan manifestasimanifestasi pada setiap kategori yang mendekati ataupun sama sesuai dengan basis aturan yang dimasukkan, sampai menghasilkan nilai temuan dan kemudian dapat disimpulkan.

\section{Mekanisme Inferensi}

Dalam memasukkan fakta kedalam database memiliki sejumlah manifestasi tang terkadang sama. Maka dari itu perlu dikelompokkan berdasarkan kategori status akreditasi. Sistem pakar melakukan perhitungan jumlah temuannya. Sistem pakar dapat menyimpulkan kategori status akreditasi yang dimungkinkan terjadi.

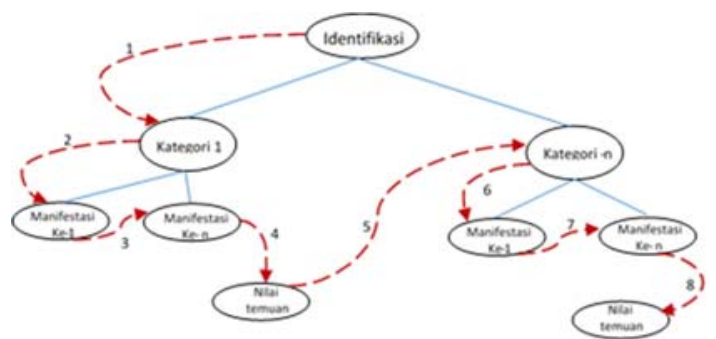

Gambar 4. Bentuk Pohon Penelusuran Depth First Search (sumber: Arhami, 2005)

Penjelasan :

a. Penelusuran pertama mengidentifikasi kategori tingkat 1 .

b. Penelusuran dilanjutkan dengan mengindentifikasi setiap manifestasi dari kategori 1. Jika temuan pada setiap manifestasi cocok dengan manifestasi yang dimasukkan oleh user, maka akan dihasilkan nilai temuan yang cocok.

c. Penelusuran dilanjutkan ke kategori tingkat $-\mathrm{n}$, dengan mengidentifikasi manifestasi dari inputan yang dimasukkan user, sehingga ditemukan nilai kecocokan untuk jenis kategori tersebut.

d. Nilai temuan dari masing-masing kategori dibandingkan.

\subsubsection{Fuzzy Logic Method}

Fuzzy Logic Method adalah logika kabur atau mengandung unsur ketidakpastian. Fuzzy Logic mengenal nilai antara benar dan salah. Kebenaran dalam Fuzzy Logic dapat dinyatakan dalam derajat kebenaran yang nilainya antara 0 sampai 1 [12].

Fuzzy Logic Method dapat digambarkan dengan kotak hitam yang menghubungan antara input dan output. Didalam kotak hitam tersebut terdapat metode atau cara yang dapat digunakan untuk mengolah data dari input menjadi output kedalam bentuk informasi yang baik.

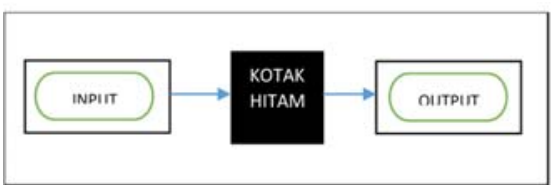

Gambar 5. Pemetaan Input - Output (sumber: Kusumadewi \& Purnomo, 2010)

Pada gambar 5 terdapat pemetaan yang menggambarkan bahwa sebelum inpur menjadi output terdapat kotak hitam diantaranya yang berarti bawa data atau infomrasi inputan akan masuk kedalam kotak hitam yang berisi metode dan cara untuk mengolah data kemudian dikirim ke output jika data yang diolah telah selesai dan menghasilkan informasi [13].

\section{Kendali Fuzzy Logic}

Kendali Fuzzy Logic disebut juga dengan sistem inferensi fuzzy (Fuzzy Inference System / FIS) adalah sistem yang dapat melakukan penalaran dengan nalurinya. Sistem kendali Fuzzy Logic terdiri dari beberapa tahapan seperti pada diagram berikut.

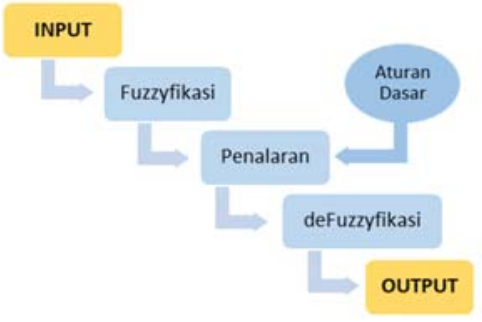

Gambar 6. Proses Kendali Fuzzy Logic (sumber: Kusumadewi \& Purnomo, 2010)

Gambar 6 menjelaskan input yang diberikan berupa bilangan tertentu dan output yang dihasilkan juga harus berupa bilangan tertentu. Fuzzyfikasi merupakan pemetaan nilai input kedalam fungsi keanggotaan himpunan Fuzzy, untuk kemudian diolah dalam mesin penalaran. Dalam kendali Fuzzy Logic aturan dasar adalah aturan implikasi dalam bentuk "jika x maka y". Aturan dasar ditentukan dengan bantuan seorang pakar yang mengetahui karakteristik ibjek yang akan dikendalikan. Pada tahap penalaran sistem menalar nilai masukan untuk menentukan nilai keluaran sebagai bentuk pengambil keputusan. Terakhir adalah deFuzzyfikasi yang merupakan kebalikan dari Fuzzyfikasi, yaitu pemetaan dari himpunan Fuzzy ke himpunan tegas, inputan dari deFuzzyfikasi adalah suatu himpunan Fuzzy yang diperoleh dari komposisi aturan-aturan Fuzzy. Kemudian hasil deFuzzyfikasi merupakan output dari sistem kendali Fuzzy Logic [14].

Operasi Fuzzy Logic Method 
1. Gabungan

Gabungan antara himpunan A dan himpunan B dapat diartikan sebagai himpunan yang dekat dengan A atau dekat dengan $\mathrm{B}$.

$A \cup B \rightarrow \mu_{A \cup B}=\mu_{A}(x) \vee \mu_{B}(x)=\max \left(\mu_{A}(x), \mu_{B}(x)\right)$
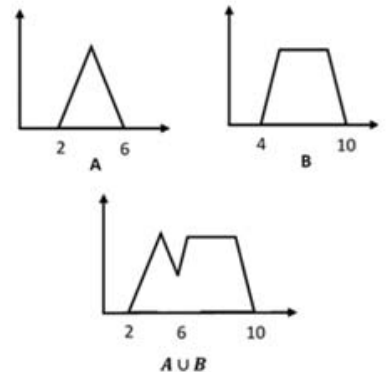

Gambar 7. Grafik Operasi Gabungan A dan B

2. Irisan

Irisan antara himpunan A dan himpunan B dapat diartikan sebagai himpunan yang dekat dengan A atau dekat dengan B.

$A \cap B \rightarrow \mu_{A \cap B}=\mu_{A}(x) \wedge \mu_{B}(x)=\min \left(\mu_{A}(x), \mu_{B}(x)\right)$
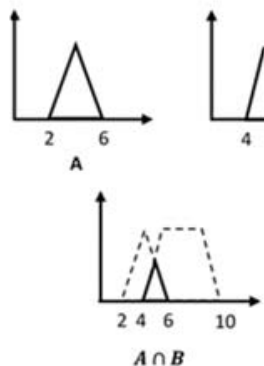

Gambar 8. Grafik Operasi Irisan A dan B

3. Komplemen

Komplemen dari himpunan A dapat diartikan sebagai himpunan yang tidak dengan A.

$\bar{A} \rightarrow \mu_{\bar{A}}=1-$

$\mu_{\bar{A}}(x)$

(3)
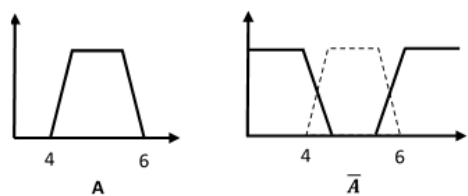

Gambar 9. Grafik Hasil Operasi Komplemen Himpunan A

Fungsi Keanggotaan Fuzzy Logic Method

Fungsi keanggotaaan adalah kurva yang menunjukkan pemetaan titik-titik nilai input data ke dalam nilai keanggotaan diantara interval 0 sampai 1. Melalui pendekatan fungsi maka akan didapatkan nilai keanggotaan, ada beberapa fungsi yang dapat digunakan.

1. Representasi linear

Pada representasi linear, pemetaan input kedalam derajat keanggotaan digambarkan sebagai suatu garis lurus. Ada 2 keadaan himpunan fuzzy yang linear. Pertama, kenaikan himpunan dimulai pada nilai domain yang memiliki derajat keanggotaan nol bergerak ke kanan menuju ke nilai domain yang memiliki derajat keanggotaan lebih tinggi [15].

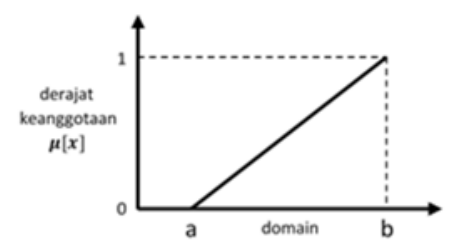

Gambar 10. Grafik Representasi Linear Naik Fungsi keanggotaan

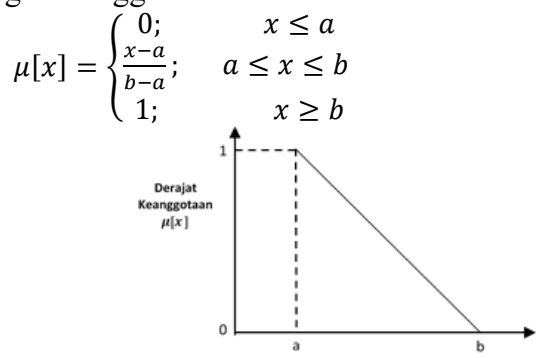

Gambar 11. Grafik Representasi Linear Turun

Fungsi keanggotaan

$$
\mu[x]=\left\{\begin{array}{lr}
\frac{b-x}{b-a} ; & a \leq x \leq b \\
0 ; & x \geq b
\end{array}\right.
$$

2. Representasi kurva segitiga

Kurva segitiga merupakan gabungan antara 2 garis (linear).

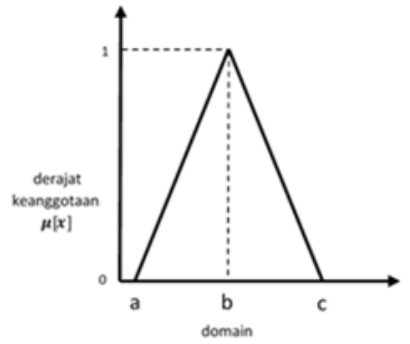

Gambar 12. Kurva Segitiga

Fungsi keanggotaan

$$
\mu[x]=\left\{\begin{array}{cc}
0 ; & x \leq \text { a atau } x \geq c \\
\frac{x-a}{b-a} ; & a \leq x \leq b \\
\frac{c-x}{c-b} ; & b \leq x \leq c
\end{array}\right.
$$

3. Representasi kurva bahu

Kurva bahu kiri bergerak dari benar ke salah, bahu kanan bergerak dari salah ke benar. Daerah yang terletak di tengah-tengah suatu variable yang direpresentasikan dalam bentuk segitiga, pada sisi kanan dan kirinya akan naik turun.

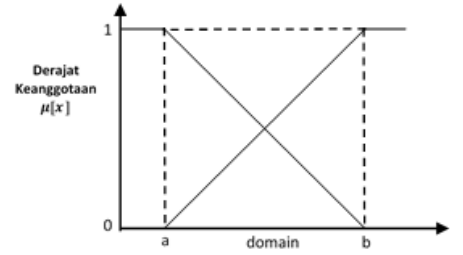

Gambar 13. Grafik Representasi Kurva Bahu Fungsi keanggotaan kurva bahu kiri

$$
\mu[x]=\left\{\begin{array}{rc}
1 ; & x \leq a \\
\frac{b-x}{b-a} ; & a \leq x \leq b \\
0 ; & x \geq b
\end{array}\right.
$$


Fungsi keanggotaan kurva bahu kanan

$$
\mu[x]=\left\{\begin{array}{rc}
0 ; & x \leq a \\
\frac{x-a}{b-a} ; & a \leq x \leq b \\
1 ; & x \geq b
\end{array}\right.
$$

Metode Fuzzy Inference System (FIS) Tsukamoto

Sistem inferensi fuzzy merupakan kerangka komputasi yang berdasa pada teori himmpunan fuzzy, aturan fuzzy yang berbentuk IF-THEN, dan penalaran fuzzy [16].

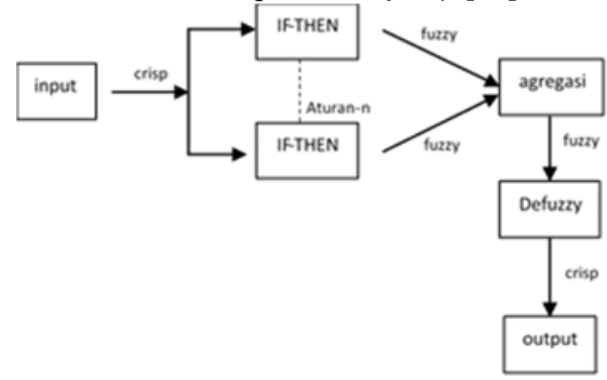

Gambar 14. Diagram Blok Inferensi Fuzzy (sumber : Kusumadewi \& Hartati, 2006:34)

Gambar 14 menjelaskan bahwa sistem inferensi menerima input crisp. Kemudian inputan crisp dikirim kedalam basis pengetahuan yang berisi $n$ aturan fuzzy dalam bentuk IF THEN. Nilai keanggotaan $\alpha$ (anteseden) akan dicari pada setiap aturan. Apabila terdapat lebih dari satu aturan maka akan dilakukan agregasi semua aturan. Kemudian hasil agregasi akan dilakukan defuzzy untuk mendapatkan nilai crisp sebagai output sistem.

Salah satu metode FIS yang digunakan untuk pengambilan keputusan adalah metode Tsukamoto. Pada metode Tsukamoto setiap aturan direpresentasikan menggunakan himpunan-himpunan fuzzy, dengan fungsi keanggotaan yang monoton. Setiap aturan berbentuk implikasi dari "IF-THEN"/ implikasi "Input-Output" dimana $\alpha$ dan konsekuen harus saling berhubungan. Untuk menentukan nilai hasil tegas (crisp) digunakan rumus penegasan (deFuzzy) yang disebut metode rata-rata terpusat atau metode deFuzzyfikasi rata-rata terpusat [17]. Metode deFuzzyfikasi yang digunakan dalam metode Tsukamoto adalah metode rata-rata terpusat yang dirumuskan pada persamaan berikut.

$$
\mathrm{Z}=\frac{\Sigma_{i=1}^{n} \alpha i z i}{\sum_{i=1}^{n} \alpha i}
$$

$$
\mathrm{Z}=\text { crisp/ nilai tegas }
$$

\subsubsection{Analisis}

Parameter Status Akreditasi

Dalam menentukan status akreditasi terdapat beberapa parameter yang digunakan berdasarkan dari hasil observasi dan wawancara narasumber. Observasi dan wawancara dilakukan pada kantor Lembaga Penjaminan Mutu dan Audit Internal (LPMAI) UKSW serta ketentuan yang berdasarkan Badan Akreditasi Nasional Perguruan Tinggi (BAN-PT). Komponen parameter penentuan status akreditasi meliputi dari (masa akreditasi), status boring (data pengajuan), status penilaian (status penilaian asesor).

Tabel 1 Komponen Parameter Status Akreditasi

\begin{tabular}{cl}
\hline No & \multicolumn{1}{c}{ Komponen } \\
\hline 1 & Hari (masa akreditasi) \\
\hline 2 & Status borang (data pengajuan) \\
\hline 3 & Status penilaian (status penilain asesor) \\
\hline
\end{tabular}

Pengumpulan Data

Berdasarkan hasil observasi dan wawancara, penulis mendapatkan data komponen parameter status akreditasi

\begin{tabular}{|c|c|c|c|}
\hline Variabel & \multicolumn{2}{|c|}{ Status } & Nilai \\
\hline \multirow{3}{*}{ Hari } & \multicolumn{2}{|c|}{ Tanpa peringatan } & 243 \\
\hline & \multicolumn{2}{|c|}{ Peringatan Awal } & 183 \\
\hline & \multicolumn{2}{|c|}{ Peringatan Akhir } & 22 \\
\hline \multirow{2}{*}{ Status borang } & \multicolumn{2}{|c|}{ Upload } & 5 \\
\hline & \multicolumn{2}{|l|}{ Tidak upload } & 1 \\
\hline \multirow{3}{*}{$\begin{array}{l}\text { Status } \\
\text { penilaian }\end{array}$} & \multicolumn{2}{|l|}{ Diterima } & 5 \\
\hline & \multicolumn{2}{|l|}{ Revisi } & 3 \\
\hline & \multicolumn{2}{|c|}{ Tidak diterima } & 1 \\
\hline \multicolumn{4}{|c|}{ Tabel 3 Data Observasi } \\
\hline Variabel & $\begin{array}{l}\text { Status } 1 \\
\text { (a) }\end{array}$ & $\begin{array}{c}\text { Status } 2 \\
\text { (b) }\end{array}$ & $\begin{array}{l}\text { Status } 3 \\
\text { (c) }\end{array}$ \\
\hline Hari & 243 hari & 183 hari & 22 hari \\
\hline Status Borang & 5 & - & 1 \\
\hline Status Penilaian & 5 & 3 & 1 \\
\hline
\end{tabular}
program studi.

Tabel 2 Transformasi Data

Teknik Penerapan Metode Inferensi Fuzzy Tsukamoto

Setiap variable/parameter tersiri dari 3 himpunan fuzzy yaitu status 1, status 2, dan status 3 . Fungsi keanggotaan hari, status boring, status penilaian, dan batasan yang direpresentasikan dalam grafik.

1. Hari

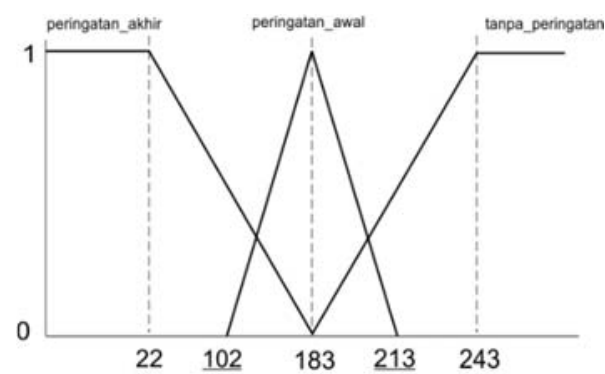

Gambar 15. Grafik Fungsi Keanggotaan Variabel Hari

$$
\begin{gathered}
\mu \text { Tanpa_Peringatan }(\mathrm{x})=\left\{\begin{array}{lc}
0 ; & x \leq 183 \\
\frac{x-183}{50} ; & 183 \leq x \leq 243
\end{array}\right. \\
\mu \text { Peringatan_Awal }(\mathrm{x})=\left\{\begin{array}{lc}
0 ; & x \geq 243 \\
\frac{x-102}{81} ; & 102 \leq x \leq 183 \\
\frac{213-x}{30} ; & 183 \leq x \leq 213
\end{array}\right. \\
\mu \text { Peringatan_Ahir }(\mathrm{x})=\left\{\begin{array}{lc}
1 ; & x \leq 22 \\
\frac{183-x}{161} ; & \leq 2 \leq 183 \\
0 ; & x \geq 183
\end{array}\right.
\end{gathered}
$$

2. Status borang 


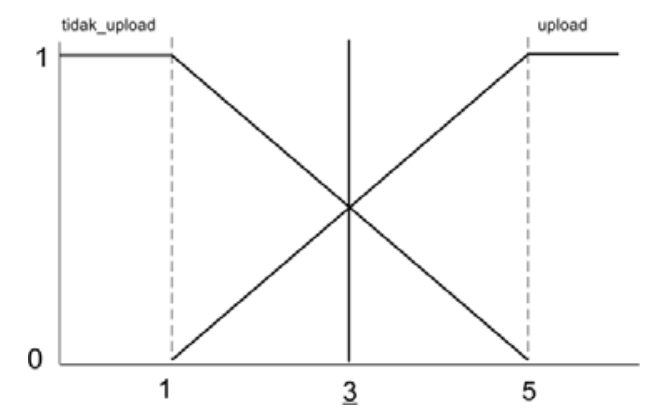

Gambar 16. Grafik Fungsi Keanggotaan Variabel Status Borang

$$
\begin{aligned}
& \mu \text { Tidak_Upload }(y)=\left\{\begin{array}{lr}
1 ; & y \leq 1 \\
\frac{5-x}{4} ; 1 \leq y \leq 5 \\
0 ; & y \geq 5
\end{array}\right. \\
& \mu \operatorname{Upload}(\mathrm{y})=\left\{\begin{array}{lr}
0 ; & y \leq 1 \\
\frac{y-1}{4} ; & 1 \leq y \leq 5 \\
1 ; & y \geq 5
\end{array}\right.
\end{aligned}
$$

3. Status penilaian

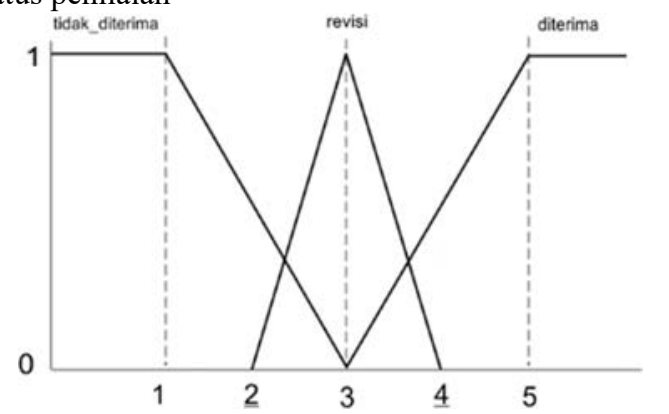

Gambar 17. Grafik Fungsi Keanggotaan Variabel Status Penilaian

4. Batasan

$$
\begin{aligned}
& \mu \text { Tidak_Diterima }(\mathrm{w})=\left\{\begin{array}{lr}
1 ; & w \leq 1 \\
\frac{3-w}{2} ; & 1 \leq w \leq 3 \\
0 ; & w \geq 3
\end{array}\right. \\
& \mu \operatorname{Revisi}(\mathrm{w})=\left\{\begin{array}{lr}
0 ; & w \leq 2 \text { atau } \geq 4 \\
\frac{w-2}{1} ; & 2 \leq w \leq 3 \\
\frac{4-w}{1} ; & 3 \leq w \leq 4
\end{array}\right. \\
& \mu \text { Diterima }(w)=\left\{\begin{array}{lr}
0 ; & w \leq 3 \\
\frac{w-3}{2} ; & 3 \leq w \leq 5 \\
1 ; & w \geq 5
\end{array}\right.
\end{aligned}
$$

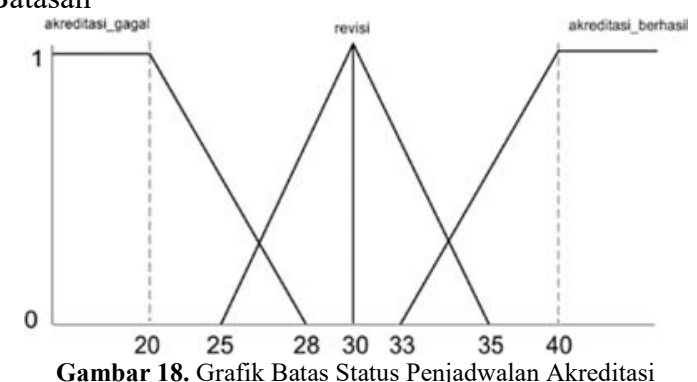

$$
\mu \text { Akreditasi_gagal }(\mathrm{z})=\left\{\begin{array}{cc}
1 ; & z \leq 20 \\
\frac{28-z}{8} ; & 20 \leq z \leq 28 \\
0 ; & z \geq 28
\end{array}\right.
$$

$$
\begin{gathered}
\mu \text { Revisi }(\mathrm{z})=\left\{\begin{array}{lc}
0 ; & z \leq 25 \text { atau } \geq 35 \\
\frac{z-25}{5} ; & 22 \leq z \leq 30 \\
\frac{35-z}{5} ; & 30 \leq z \leq 35
\end{array}\right. \\
\mu \text { Akreditasi_berhasil(z) }=\left\{\begin{array}{cc}
\frac{0 ;}{z-33} & z \leq 33 \\
1 ; & 33 \leq z \leq 40
\end{array}\right.
\end{gathered}
$$

\begin{tabular}{|c|c|}
\hline [R1] & $\begin{array}{l}\text { IF hari=peringatan_awal AND } \\
\text { borang=upload AND nilai=tidak_diterima } \\
\text { THEN status=akreditasi gagal. }\end{array}$ \\
\hline [R2] & $\begin{array}{l}\text { IF hari=peringatan awal } \\
\text { borang=upload AND nilai=revisi } \\
\text { status=revisi borang pengajuan. }\end{array}$ \\
\hline [R3] & $\begin{array}{l}\text { IF hari=peringata_awal AND } \\
\text { borang=upload AND nilai=diterima } \\
\text { THEN status=akreditasi berhasil. }\end{array}$ \\
\hline $\begin{array}{ll}4 & {[\mathrm{R} 4]}\end{array}$ & $\begin{array}{l}\text { IF hari=peringatan_akhir AND } \\
\text { borang=upload AND nilai=tidak_diterima } \\
\text { THEN status=akreditasi gagal. }\end{array}$ \\
\hline [R5] & $\begin{array}{l}\text { IF hari=peringatan akhir } \\
\text { borang=upload AND nilai=revisi } \\
\text { status=revisi borang pengajuan. }\end{array}$ \\
\hline [R6] & $\begin{array}{l}\text { IF hari=peringatan_akhir AND } \\
\text { borang=upload AND nilai=diterima } \\
\text { THEN status=akreditasi berhasil. }\end{array}$ \\
\hline [R7] & $\begin{array}{l}\text { IF hari=tanpa_peringatan AND } \\
\text { borang=upload AND nilai=tidak_diterima } \\
\text { THEN status=akreditasi gagal. }\end{array}$ \\
\hline [R8] & $\begin{array}{l}\text { IF hari=tanpa_peringatan } \\
\text { borang=upload AND nilai=revisi } \\
\text { status=revisi borang pengajuan. }\end{array}$ \\
\hline [R9] & $\begin{array}{l}\text { IF hari=tanpa peringatan AND } \\
\text { borang=upload AND nilai=diterima } \\
\text { THEN status=akreditasi berhasil. }\end{array}$ \\
\hline [R10] & $\begin{array}{l}\text { IF hari=tanpa_peringatan } \\
\text { borang=tidak_upload } \\
\text { nilai=tidak_diterima } \\
\text { status=akreditasi gagal. }\end{array}$ \\
\hline
\end{tabular}

Rule (aturan)

Menurut hasil observasi dan wawancara dilapangan, didapatkan 10 rule/aturan dalam menentukan status akreditasi program studi yang digunakan sebagai dasar dalam merancang basis pengetahuan dalam system.

Tabel 4 Rule Penjadwalan Akreditasi

Menentukan Output Crisp (deFuzzyfikasi)

Tahap deFuzzyfikiasi merupakan tahap untuk menentukan output nilai tegas/crisp berdasarkan pembentukan rule sehingga nantinya akan diperoleh nilai rata-rata terpusat untuk menentukan hasil kesimpulan status akreditasi.

$$
z=\frac{a_{1 .} z_{1}+\cdots+a_{n .} z_{n}}{a_{1}+\cdots+a_{n}}
$$

\section{METODE PENELITIAN}

Tahapan penelitian dapat dilihat sebagaimana pada gambar 19. Setiap tahap memiliki beberapa bagian yaitu terdiri dari tujuan yang ingin dicapai pada tahap tersebut, 
metode / alat/ bahan yang digunakan untuk mencapai tahap tersebut, serta output yang akan dihasilkan pada tahap tersebut.

\begin{tabular}{|c|c|}
\hline \multicolumn{2}{|r|}{ Tahap 1} \\
\hline Tujuan & : Identifikasi masalah dan analisis kebutuhan \\
\hline Metode/alat/bahan & : Wawancara, Observasi \\
\hline Output & : Indikator permasalahan, requirement system \\
\hline \multicolumn{2}{|r|}{ Tahap 2} \\
\hline Tujuan & : Pengumpula data \\
\hline Metode/alat/bahan & : Wawancara, Observasi \\
\hline Output & : Indikator penjadwalan masa akreditasi \\
\hline \multicolumn{2}{|r|}{ Tahap 3} \\
\hline Tujuan & : Desain perancangan sistem \\
\hline Metode/alat/bahan & : UML, Ms.Visio \\
\hline Output & : Diagram UML, User interface \\
\hline \multicolumn{2}{|r|}{ Tahap 4} \\
\hline Tujuan & \multirow{3}{*}{$\begin{array}{l}\text { : Pengkodean rancangan sistem } \\
\text { : PHP, MySQL } \\
\text { : Sistem penjadwalan }\end{array}$} \\
\hline Metode/alat/bahan & \\
\hline Output & \\
\hline \multicolumn{2}{|r|}{ Tahap 5} \\
\hline Tujuan & : Imlementasi dan pengujian sistem \\
\hline Metode/alat/bahan & : Sistem \\
\hline Output & : Hasil pengujian sistem \\
\hline
\end{tabular}

Sebagaimana pada gambar 19 dijelaskan bahwa pada tahap pertama yang dilakukan adalah melakukan identifikasi masalah dan menganalisis kebutuhan sistem. pada tahap ini metode yang digunakan yaitu wawancara dan observasi. Wawancara dilakukan dengan Lembaga Penjaminan Mutu dan Audit Internal (LPMAI) selaku lembaga yang menfasilitasi dan bertanggung jawab terhadap penjaminan mutu dan audit internal Universitas Kristen Satya Wacana, termasuk mengenai akreditasi internal setiap program studi di UKSW. Output dari tahapan pertama menghasilkan permasalahan yang ada pada sistem penjadwalan SAPTI yang belum dimajanemen dengan baik dan tepat, serta requirements yang diperlukan guna membangun sistem yang sesuai dengan kenyataan dilapangan.

Tahap kedua adalah pengumpulan data. Data-data dikumpulkan berdasarkan indikator permasalahan dan requirements system pada tahap pertama, yang kemudian memperluas daerah pengumpulan data dengan metode wawancara dan observasi. Data yang didapatkan pada tahap ini adalah berupa indikator-indikator status akreditasi berdasarkan ketentuan dari LPMAI serta panduan yang bersumber dari Badan Akreditasi Nasional Perguruan Tinggi (BAN-PT).

Tahap ketiga adalah desain perancangan sistem. Metode perancangan sistem yang digunakan untuk membangun aplikasi sistem ini adalah metode Agile. Agile adalah kombinasi dari model proses iterative dan incremental dengan berfokus pada proses adaptasi dan kepuasan pelanggan dengan pengerjaan produk perangkat lunak yang cepat.

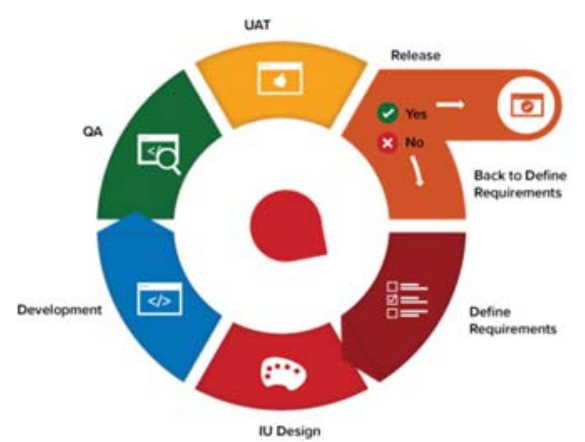

Gambar 20. Metode Agile (sumber : Smartsheet, 2018)

Gambar 20 merupakan tahap-tahap didalam model Agile yang akan diimplementasikan didalam perancangan sistem akreditasi SAPTI antara lain :

1. Define Requirements

Pada tahap ini dilakukan pengumpulan data dengan metode observasi dan wawancara untuk memenuhi kebutuhan dari sistem yang akan dibangun, berupa data kuantitatif maupun data kualitatif. Data diperoleh melalui Lembaga Penjaminan Mutu dan Audit Internal (LPMAI) Universitas Kristen Satya Wacana serta panduan akreditasi yang bersumber dari Badan Akreditasi Nasional Perguruan Tinggi (BAN-PT).

2. Development \& UI Design

Pada tahap ini dilakukan perancangan menggunakan Unified Modelling Language (UML), meliputi use case diagram yang menggambarkan fungsi-fungsi setiap aktor, sistem, dan use case sehingga akan diketahui fungsi-fungsi apa saja yang berada pada sistem. Perancangan tampilan User Interface yang kemudian semua akan dibangun menggubakan bahasa pemrograman web sesuai dengan requirement yang dibutuhkan.

3. Quality Assurance (QA)

Pada tahap ini dilakukan pengujian jaminan kualitas perancangan sistem, pelatihan internal dan eksternal, dokumentasi perancangan sistem, serta rilis akhir dari iterasi ke dalam produksi.

\section{User Acceptance Testing (UAT)}

Tahapan ini merupakan pengujian terakhir dari proses pengujuan perangkat lunak. Dalam melakukan UAT, pengguna perangkat lunak / user yang menggunakan sistem ini menguji secara langsung untuk memastikan bahwa sistem yang dirancang dapat menangani tugas yang dibutuhkan sesuai dengan scenario yang sebenarnya pada dunia nyata, sesuai dengan spesifikasi. Dalam perancangan ini, terdapat dua proses UAT yaitu pengujian white box dan pengujian black box.

5. Release

Pada tahap ini perangkat lunak telah siap untuk dilepaskan atau diserahkan kepada pelanggan. Kemudian pelanggan memberikan feedback untuk dilakukan pengambangan selanjutnya sesuai dengan kebutuhan dan perminataan pelanggan. 


\section{Arsitektur Komputer}

Dalam merancang dan membangun sistem dibutuhkan suatu desain atau rancangan / blueprint secara keseluruhan untuk memenuhi kebutuhan-kebutuhan yang spresifik. Rancangan tersebut digambarkan melalui sebuah diagram komponen-komponen yang terdapat pada suatu sistem dan proses suatu komponen yang saling berinteraksi dengan komponen lainnya.

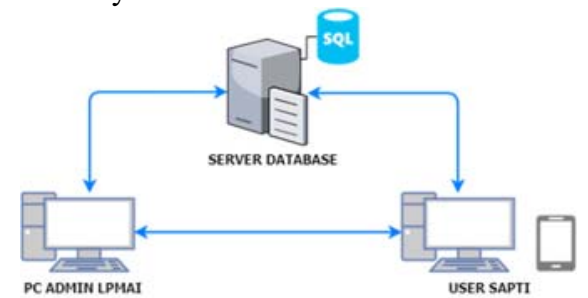

Gambar 21. Diagram Arsitektur Sistem Akreditasi SAPTI

Gambar 21 menunjukkan diagram perancangan arsitektur sistem SAPTI. Server database berfungsi menyimpan dan memanipulasi data yang diminta oleh admin maupun user SAPTI. Admin bertugas untuk memonitoring semua aktivitas user, menambah, mengubah, menghapus data sesuai dengan kebutuhan. User SAPTI adalah masing-masing program studi yang ada di UKSW dan tim Asesor penilai akreditasi program studi. ketiga komponen utama tersebut saling terhubung dan dapat berkomunikasi dua arah.

\section{HASIL DAN PEMBAHASAN}

Untuk membuktikan perhitungan sistem inferensi fuzzy dengan metode Tsukamoto apakah telah berjalan sesuai dengan tujuan dan harapan yang diinginkan maka dilakukan beberapa simulasi penjadwalan akreditasi dengan perhitungan sistem inferensi fuzzy Tsukamoto secara manual. Rincian tahap pengerjaan sistem akreditasi :

1. Input data variabel hari, status boring, penilaian

Tabel 6. Input data variabel parameter status akreditasi

$$
\text { Variabel Input }
$$

\begin{tabular}{ll}
\hline Hari & 130 hari \\
\hline Status borang & $5=$ upload \\
\hline Penilaian & $5=$ diterima
\end{tabular}

2. Pembentukan himpunan fuzzy

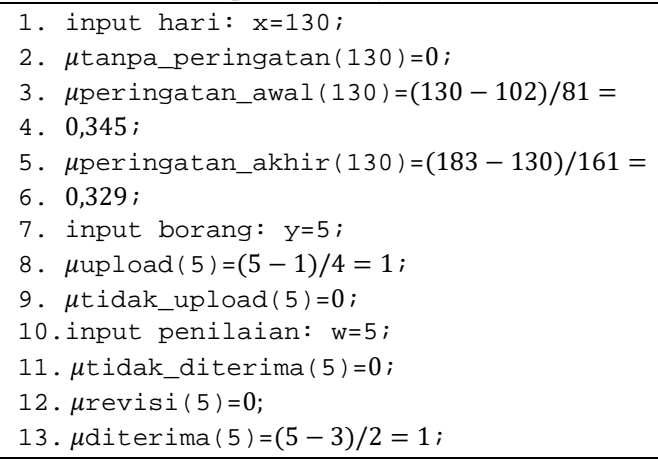

Perhitungan diatas merupakan pseudocode yang menghasilkan himpunan fuzzy untuk setiap parameter variabel yang telah ditentukan. Inputan Data variabel $\mathrm{x}, \mathrm{y}, \mathrm{w}$ dimasukkan kedalam setiap parameter fungsi anggota yang menghasilkan nilai himpunan fuzzy untuk dilakukan fungsi implikasi. Parameter hari dengan variabel x berjumlah 130 menghasilkan himpunan fuzzy tanpa peringatan $=0$, peringatan awal $=0.345$, peringatan akhir $=0.329$. Parameter status borang dengan variabel y berjumlah 5 menghasilkan himpunan fuzzy upload=1, tidak upload $=0$. Parameter status penilaian dengan variabel w berjumlah 5 menghasilkan himpunan fuzzy tidak diterima $=0$, revisi $=0$, diterima $=1$.

3. Penerapan fungsi implikasi

Nilai $\alpha$-predikat dan $\mathrm{z}$ dari setiap aturan.

\begin{tabular}{|c|c|}
\hline 1. [ & $\alpha$-predikat ${ }_{1}=\mu$ peringatan_awal $\cap$ \\
\hline 2. & $\mu$ upload \\
\hline 3. & $\cap \mu$ tidak_diterima \\
\hline 4. & $=\min (\mu$ peringatan_awal $(130) \cap$ \\
\hline 5. & $\mu$ upload(5) \\
\hline 6. & ก $\mu$ tidak_diterima(5)) \\
\hline 7. & $=\min (\odot, 345 ; 1 ; \odot)$ \\
\hline 8. & $=\odot$ \\
\hline 9. & $\Theta=(28-Z 1) / 8$ \\
\hline & $\mathrm{Z1}=28$; \\
\hline 11. & $: \alpha$-predikat ${ }_{2}=\mu$ peringatan_awal $\cap$ \\
\hline 12. & $\mu$ uploadn $\mu$ revisi \\
\hline 13. & $=\min (\mu$ peringatan_awal $(130) \cap$ \\
\hline 14. & $\mu$ upload(5) \\
\hline 15. & ก $\mu$ revisi(5)) \\
\hline 16. & $=\min (\odot, 345 ; 1 ; \odot)$ \\
\hline 17. & $=0$ \\
\hline 18. & $\Theta=(28-Z 2) / 8$ \\
\hline 19. & $Z 2=0$ \\
\hline 20. & $: \alpha$-predikat ${ }_{3}=\mu$ peringatan_awal $\cap$ \\
\hline 21. & $\mu$ upload \\
\hline 22. & $\cap \mu$ diterima \\
\hline 23. & $=\min (\mu$ peringatan_awal $(130) \cap$ \\
\hline 24. & $\mu$ upload(5) \\
\hline 25. & $\cap \mu$ diterima(5)) \\
\hline 26. & $=\min (0,345 ; 1 ; 1)$ \\
\hline 27. & $=0,345$ \\
\hline 28. & $\odot, 345=(28-Z 3) / 8$ \\
\hline & $Z 3=34,035$ \\
\hline 30. & $: \alpha$-predikat $4=\mu$ peringatan_akhir $\cap$ \\
\hline 31. & $\mu$ upload \\
\hline 32. & $\cap \mu$ tidak_diterima \\
\hline 33. & $=\min (\mu$ peringatan_akhir $(130) \cap$ \\
\hline 34. & $\mu$ upload(5) \\
\hline 35. & ก $\mu$ tidak_diterima(5)) \\
\hline 36. & $=\min (\odot, 329 ; 1 ; \odot)$ \\
\hline 37. & $=0$ \\
\hline 38. & $\Theta=(28-Z 4) / 8$ \\
\hline 39. & $Z 4=28$ \\
\hline 40 . & $: \alpha$-predikat $=\mu$ peringatan_akhir $\cap$ \\
\hline 41. & $\mu$ uploadn $\mu$ revisi \\
\hline 42. & $=\min (\mu$ peringatan_akhir $(130) \cap$ \\
\hline 43. & $\mu$ upload (5) \\
\hline 44. & ก $\mu$ revisi(5)) \\
\hline 45. & $=\min (\odot, 329 ; 1 ; \odot)$ \\
\hline 46. & $=0$ \\
\hline 47. & $\odot=(28-Z 5) / 8$ \\
\hline & $Z 5=0$ \\
\hline 49. & $: \alpha$-predikat ${ }_{6}=\mu$ peringatan_akhir $\cap$ \\
\hline 50. & $\mu$ upload \\
\hline 51. & $\cap \mu$ diterima \\
\hline 52. & $=\min (\mu$ peringatan_akhir $(130) \cap$ \\
\hline 53. & $\mu$ upload(5) \\
\hline 54. & $\cap \mu$ diterima(5)) \\
\hline & $=\min (\odot, 329 ; 1 ; 1)$ \\
\hline 56. & $=0,329$ \\
\hline 57. & $\odot, 329=(28-Z 6) / 8$ \\
\hline
\end{tabular}




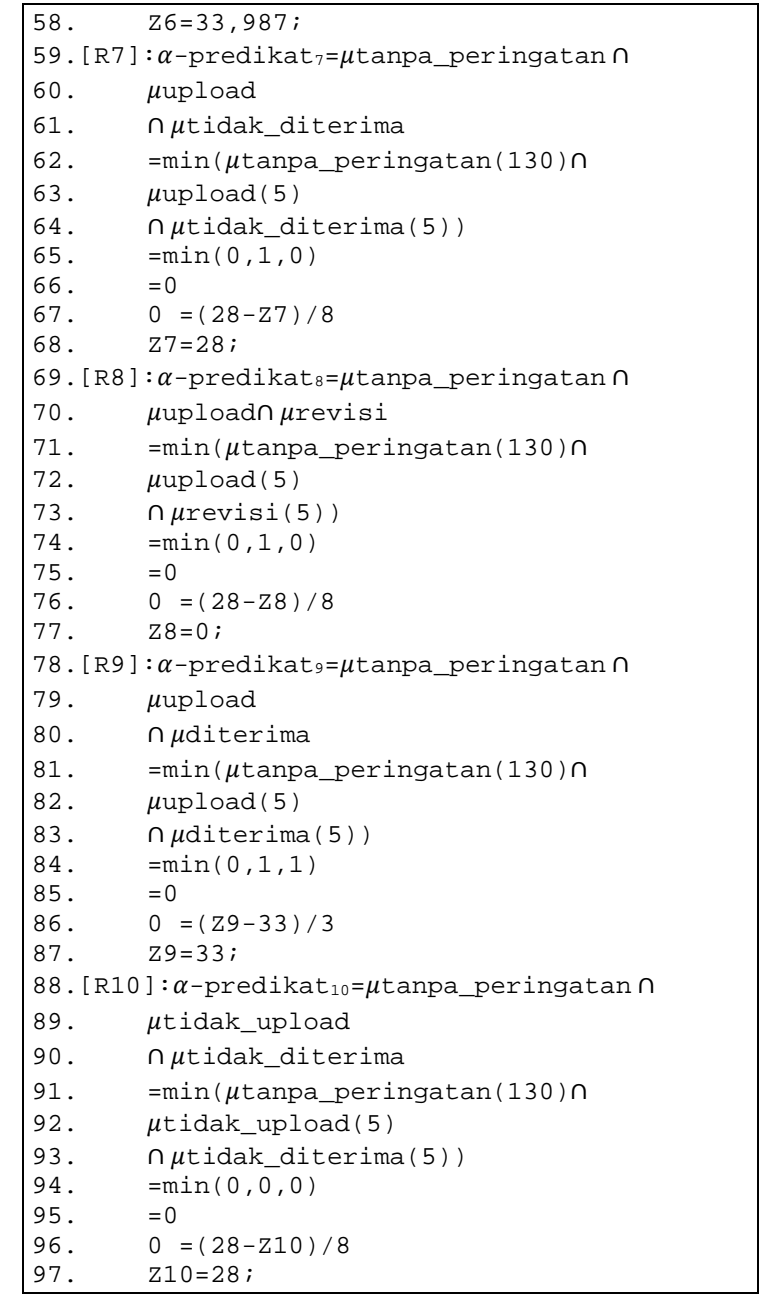

Penerapan fungsi implikasi dengan menggabungkan $\alpha$ predikat dan z (kesimpulan) dari setiap aturan. Selanjutnya dilakukan dengan fungsi implikasi "AND" menghasilkan pencarian nilai minimum untuk setiap rule dan memasukkannya kedalam batas penilaian status fungsi anggota untuk mendapatkan hasil nilai $\mathrm{z}$ setiap rule. R1 sampai dengan $\mathrm{R} 10$ merupakan aturan/rule pertama sampai dengan aturan/rule ke-sepuluh dimana setiap hasil rule tersebut merupakan variabel penentu hasil kesimpulan akreditasi pada proses deFuzzyfikasi. R1 menghasilkan nilai $\alpha$-predikat dengan nilai minimum $=0$ dan Z1 (kesimpulan aturan pertama $)=28$. R2 $\alpha$-predikat minimum $=0$ dan $\mathrm{Z} 2=0 . \mathrm{R} 3 \alpha$-predikat minimum $=$ 0,345 dan $\mathrm{Z3}=34,035$. R4 $\alpha$-predikat minimum $=0$ dan $\mathrm{Z} 4=28$. R5 $\alpha$-predikat minimum $=0$ dan Z5 $=0$. R6 $\alpha$ predikat minimum $=0,329$ dan $\mathrm{Z6}=33,987$. R7 $\alpha$ predikat minimum $=0$ dan $\mathrm{Z7}=28 . \mathrm{R} 8 \alpha$-predikat minimum $=0$ dan $Z 8=0 . \mathrm{R} 9 \alpha$-predikat minimum $=0$ dan Z9 $=33$. R10 $\alpha$-predikat minimum $=0$ dan $Z 10=28$.

4. Menentukan output crisp (deFuzzyfikasi)

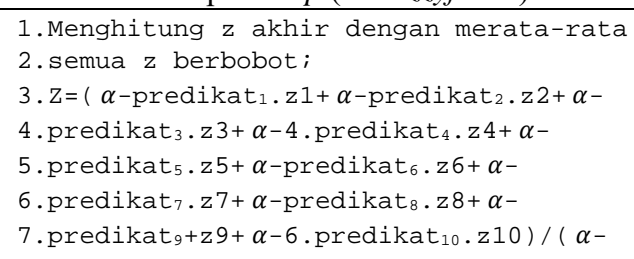

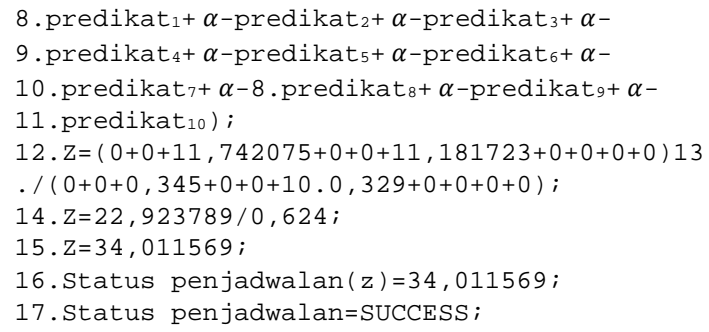

Penarikan kesimpulan secara keseluruhan dengan menggunakan deFuzzyfikasi atau rata-rata terpusat menghasilkan kesimpulan yang efektif. Hasil nilai variabel kesimpulan (Z) setiap rule dan hasil nilai $\alpha$ predikat setiap rule dihitung dengan menggunakan rumus rata-rata terpusta metode Tsukamoto dan menghasilkan nilai kesimpulan $Z$ berbobot sebesar 34,011569. Hasil nilai kesimpulan $\mathrm{Z}$ berbobot dirumuskan menjadi penilaian persen dan dilakukan perbandingan untuk menarik kesimpulan status akreditasi. Berikut perhitungan penilaian persen untuk status akreditasi.

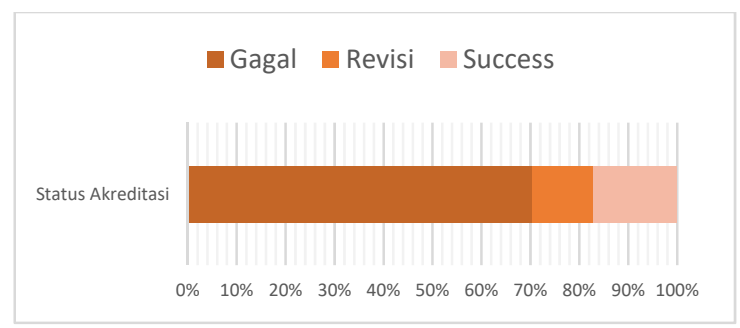

Gambar 27. Grafik Rentang Penilaian Persen Status Akreditasi

Gambar 27. Merupakan grafik rentang penilaian persen status akreditasi yang didapatkan berdasarkan grafik keanggotan batasan pada pembahasan sebelumnya dengan merubah nilai batasan-batasan menjadi nilai persen agar lebih mudah dalam memahami dan melakukan perbandingan hasil nilai $\mathrm{Z}$ berbobot. Status gagal akreditasi terdapat pada rentang nilai $0 \%-70 \%$, dengan pengertian bahwa hasil nilai persen $\mathrm{Z}$ berbobot yang berada pada rentang nilai tersebut maka dinyatakan status akreditasi gagal. Status revisi akreditasi pada rentang 70\%-82,5\%, dengan pengertian bahwa hasil nilai persen $\mathrm{Z}$ berbobot yang berada pada rentang nilai tersebut maka dinyatakan status akreditasi revisi. Status sukses akreditasi pada rentang $82,5 \%-100 \%$, dengan pengertian bahwa hasil nilai persen $\mathrm{Z}$ berbobot yang berada pada rentang nilai tersebut maka dinyatakan status akreditasi sukses. Pada hasil nilai kesimpulan $\mathrm{Z}$ berbobot pada perhitungan sebelumnya adalah 34,011569 . Selanjutnya dilakukan perhitungan nilai persen $=(34,01 / 40) * 100 \%=$ $85,025 \%$. Sehingga dapat ditarik kesimpulan bahwa nilai $\mathrm{Z}$ berbobot sebesar $85,025 \%$ dinyatakan berada pada rentang nilai status akreditasi sukses.

Implementasi

Perhitungan sistem inferensi fuzy Tsukamoto diterapkan pada sistem dengan hasil release berupa tampilan / desain user interface yang mudah dimenerti dalam pengoperasian sistem oleh pengguna / user.

1. Tampilan status sisa hari untuk pengajuan akreditasi 


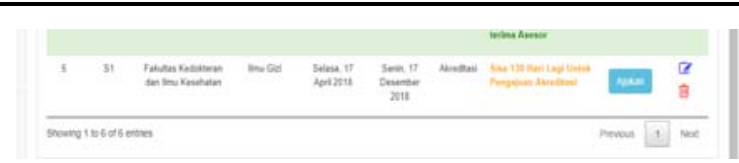

Gambar 28. Tampilan status sisa hari akreditasi

Gambar 28. Merupakan tampilan status akreditasi yang menunjukkan sisa hari untuk pengajuan akreditasi (status berwarna orange) kepada program studi. Tampak 130 hari lagi untuk melakukan pengajuan akreditasi.

Simulasi menentukan status akrediasi pada tampilan user interface disesuaikan dengan perhitungan manual pada pembahasan sebelumnya.

2. Tampilan status boring telah di upload

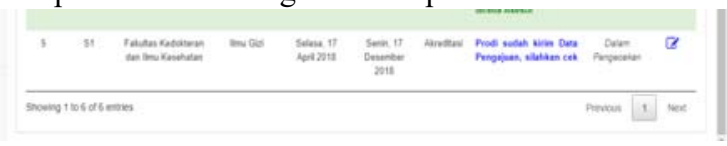

Gambar 29. Tampilan Status Borang Akreditasi

Gambar 29. Menjelaskan status borang / data pengajuan telah dikirim oleh program studi. Jika program studi telah mengirim / upload borang sesuai dengan tenggat waktu yang ditentukan maka status akan berubah "prodi telah mengirimkan data pengajuan" (status berwarna biru), namun jika program studi tidak mengirimkan / upload data pengajuan maka status akan berubah "prodi tidak mengirimkan data pengajuan, akreditasi gagal" (status berwarna merah). Sesuai dengan simulasi pada perhitungan manual sebelumnya, status pada gambar terlihat prodi telah mengirimkan data pengajuan.

3. Tampilan status asesor telah melakukan penilaian

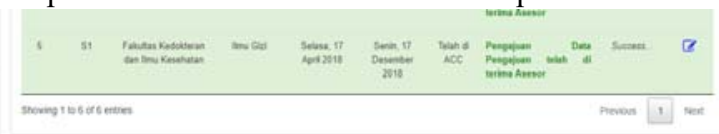

Gambar 30. Tampilan Status Akreditasi Telah Berhasil

Gambar 30. Menjelaskan status data pengajuan telah diterima asesor (status berwarna hijau) yang berarti bahwa borang/data pengajuan yang telah dikirimkan kepada asesor, kemudian asesor telah melakukan penilaian bahwa data pengajuan diterima. Maka status akreditasi yang muncul sesuai dengan perhitungan manual padapembahasan sebelumnya yaitu "Sukses". Maka dapat disimpulkan bahwa antara perhitungan manual pada pembahasan sebelumnya dengan implementasi pada sistem terjadi kecocokan.

Pengujian Sistem

Untuk memastikan bahwa sistem informasi telah berjalan dengan baik dan benar maka dilakukan pengujian sistem dengan metode pengujian alpha testing. Metode alpha testing merupakan pengujian pada tahap pertama yang dilakukan oleh pengembang sebelum diluncurkan secara resmi kepada pihak pengguna dilapangan.

\begin{tabular}{cccccc}
\hline No & Data Uji & Input & $\begin{array}{c}\text { Hasil Yang } \\
\text { Diharap- } \\
\text { kan }\end{array}$ & OutPut & $\begin{array}{c}\text { Kesimpu } \\
\text { lan }\end{array}$ \\
\hline 1. & Login & $\begin{array}{l}\text { Login dengan } \\
\text { username dan }\end{array}$ & $\begin{array}{c}\text { Dapat } \\
\text { masuk ke }\end{array}$ & $\begin{array}{c}\text { Dapat } \\
\text { masuk ke }\end{array}$ & Valid \\
\hline
\end{tabular}

\begin{tabular}{|c|c|c|c|c|c|}
\hline & & $\begin{array}{c}\text { password } \\
\text { yang sesuai }\end{array}$ & $\begin{array}{c}\text { halaman } \\
\text { utama }\end{array}$ & $\begin{array}{l}\text { halaman } \\
\text { utama }\end{array}$ & \\
\hline & & $\begin{array}{l}\text { Login dengan } \\
\text { username dan } \\
\text { password } \\
\text { yang tidak } \\
\text { sesuai }\end{array}$ & $\begin{array}{l}\text { Muncul } \\
\text { peringatan } \\
\text { kesalahan } \\
\text { login }\end{array}$ & $\begin{array}{c}\text { Muncul } \\
\text { peringata } \\
\mathrm{n} \\
\text { kesalahan } \\
\text { login }\end{array}$ & Valid \\
\hline \multirow[t]{2}{*}{2.} & $\begin{array}{c}\text { Tambah } \\
\text { data } \\
\text { akreditasi }\end{array}$ & $\begin{array}{c}\text { Masukan data } \\
\text { akreditasi }\end{array}$ & $\begin{array}{c}\text { Menyimpan } \\
\text { data } \\
\text { akreditasi } \\
\text { ke halaman } \\
\text { akreditasi }\end{array}$ & $\begin{array}{c}\text { Menyimp } \\
\text { an data } \\
\text { akreditasi } \\
\text { ke } \\
\text { halaman } \\
\text { akreditasi }\end{array}$ & Valid \\
\hline & & $\begin{array}{l}\text { Masukan data } \\
\text { akreditasi } \\
\text { tidak lengkap }\end{array}$ & $\begin{array}{c}\text { Muncul } \\
\text { peringatan } \\
\text { data harus } \\
\text { diisi } \\
\text { lengkap }\end{array}$ & $\begin{array}{c}\text { Muncul } \\
\text { peringata } \\
\mathrm{n} \text { data } \\
\text { harus } \\
\text { diisi } \\
\text { lengkap }\end{array}$ & Valid \\
\hline \multirow[t]{2}{*}{3.} & $\begin{array}{c}\text { Ubah } \\
\text { data } \\
\text { akreditasi }\end{array}$ & $\begin{array}{l}\text { Masukan data } \\
\text { akreditasi }\end{array}$ & $\begin{array}{c}\text { Data } \\
\text { berhasil } \\
\text { diubah, } \\
\text { kembali ke } \\
\text { halaman } \\
\text { akreditasi }\end{array}$ & $\begin{array}{c}\text { Data } \\
\text { berhasil } \\
\text { diubah, } \\
\text { kembali } \\
\text { ke } \\
\text { halaman } \\
\text { akreditasi }\end{array}$ & Valid \\
\hline & & $\begin{array}{l}\text { Masukan data } \\
\text { akreditasi } \\
\text { tidak lengkap }\end{array}$ & $\begin{array}{c}\text { Muncul } \\
\text { peringatan } \\
\text { data harus } \\
\text { diisi } \\
\text { lengkap }\end{array}$ & $\begin{array}{c}\text { Muncul } \\
\text { peringata } \\
\mathrm{n} \text { data } \\
\text { harus } \\
\text { diisi } \\
\text { lengkap }\end{array}$ & Valid \\
\hline 4 & $\begin{array}{c}\text { Hapus } \\
\text { data } \\
\text { akreditasi }\end{array}$ & $\begin{array}{c}\text { Pilih } \\
\text { akreditasi } \\
\text { yang akan } \\
\text { dihapus }\end{array}$ & $\begin{array}{c}\text { Data } \\
\text { produk } \\
\text { terhapus, } \\
\text { kembali ke } \\
\text { halaman } \\
\text { akreditasi }\end{array}$ & $\begin{array}{c}\text { Data } \\
\text { produk } \\
\text { terhapus, } \\
\text { kembali } \\
\text { ke } \\
\text { halaman } \\
\text { akreditasi }\end{array}$ & Valid \\
\hline 5 & $\begin{array}{l}\text { Status } \\
\text { sisa hari }\end{array}$ & $\begin{array}{c}\text { Ubah tanggal } \\
\text { pada sistem } \\
\text { laptop }\end{array}$ & $\begin{array}{c}\text { Muncul } \\
\text { status sisa } \\
\text { hari } \\
\text { akreditasi } \\
\text { sesuai } \\
\text { dengan } \\
\text { tanggal }\end{array}$ & $\begin{array}{c}\text { Muncul } \\
\text { status } \\
\text { sisa hari } \\
\text { akreditasi } \\
\text { sesuai } \\
\text { dengan } \\
\text { tanggal }\end{array}$ & Valid \\
\hline
\end{tabular}

\section{SIMPULAN}

Sistem pakar Fuzzy Logic Method dengan metode inferensi fuzzy Tsukamoto efektif digunakan untuk menarik suatu kesimpulan dari beberapa permasalahan dengan variabel-variabel yang bervariasi. Hal ini dapat dilihat dari hasil penarikan kesimpulan status akreditasi dalam satu kasus kondisi pada sistem akreditasi SAPTI. Menghasilkan nilai sebesar $85,025 \%$ yang masuk dalam rentang nilai status akreditasi sukses sesuai dengan yang diharapkan. Implementasi sistem pakar Fuzzy Logic Method dengan metode inferensi fuzzy Tsukamoto untuk menentukan status akreditasi, diaharapkan dapat mengelola dan memberikan penilaian yang akurat terhadap sistem akreditasi yang berjalan di Universitas Kristen Satya Wacana.

\section{DAFTAR PUSTAKA}

https://banpt.or.id/direktori/prodi/pencarian_prodi, diakses 14 Februari 2018.

Chandra W., Julian, \& Rajab F., Muhammad, Pengembangan Sistem Informasi Penjadwalan dan Manajemen Keuangan Kegiatan Seminar dan Sidang Skripsi/Tugas Akhir (Studi Kasus Program 
Studi Sistem Informasi UNIKOM), Jurnal Teknik Informatika dan Sistem Informasi Volume 3, Nomor 1, April 2017.

[3] Listiyono, 2008, Merancang dan Membuat Sistem Pakar, Jurnal Teknologi Informasi DINAMIK Volume XIII, No.2, Juli 2008 : 115124.

[4] Wibowo, Setyoningsih, 2015, Penerapan Logika Fuzzy Dalam Penjadwalan Waktu Kuliah, Jurnal Informatika UPGRIS, Volume 1 Edisi Juni 2015.

[5] Sugiarto, Edi, Sri Winarno, Amiq Fahmi, 2015, Penjadwalan Perkuliahan Otomatis Berbasis Fuzzy Logic dan Genetic Algorithm Pada Universitas Dian Nuswantoro, Jurnal Techno.com, Vol. 14, No.4, November 2015: 315-328.

[6] Suhartono, Rachmad, dan Suyanto, 2012, Pengembangan Aplikasi Penjadwalan Pasien-Dokter Berbasis Logika Samar (Fuzzy Logic) dan Algoritma Genetika (Genetic Algorithm), Karya Ilmiah, Universitas Telkom, No. 113080128, 2012.

[7] Dahria, 2011, Pengembangan Sistem Pakar Dalam Membangun Suatu Aplikasi, Jurnal SAINTIKOM Vol. 10/No.3/September 2011 : 199 .

[8] Listiyono, 2008, Merancang dan Membuat Sistem Pakar, Jurnal Teknologi Informasi DINAMIK Volume XIII, No.2, Juli 2008 L 115124.

[9] Dahria, 2011, Pengembangan Sistem Pakar Dalam Membangun suatu Aplikasi, Jurnal SAINTIKOM Vol. 10/No.3/September 2011 $: 200$.

[10] Dahria, 2011, Pengembangan Sistem Pakar Dalam Membangun suatu Aplikasi, Jurnal SAINTIKOM Vol. 10/No.3/September 2011 $: 201$.

[11] Wijaya, 2007, Penggunaan Sistem Pakar dalam Pengembangan Portal Informasi untuk Spesifikasi Jenis Penyakit Infeksi, Jurnal Informatika, Vol.3, No.1, Juni 2007 : 69.

[12] Saelan, 2009, Logika Fuzzy, Makalah IF2091 Struktur Diskrit.

[13] Masykur, 2012, Implementasi Sistem Pakar Diagnosis Penyakit Diabetes Mellitus Menggunakan Metode Fuzzy Logic Berbasis Web, https://eprints.undip.ac.id/36016/, diakses tanggal 21 Februari 2018.

[14] Nainggolan, Logika Fuzzy (Fuzzy Logic) : teori dan Penerapan Pada Sistem Daya (Kajian Pengaruh Induksi Mesin Magnet), http://member,unila.ac.id/ ftelektro/lab/ltpe/dokumen/Fuzzy\%20Logic\%20Paper.doc, diakases tanggal 21 Februari 2018.

[15] Kusumadewi, S., dan Purnomo, S. 2010. Aplikasi Logika Fuzzy untuk Pendukung Keputusan. Yogyakarta : Graha Ilmu.

[16] Kusumadewi, Sri, dan Hartati, Sri. 2006. Neuro Fuzzy-Integrasi Sistem Fuzzy dan Jaringan Syaraf. Yogyakarta : Graha Ilmu.

[17] Setiadji. 2009. Himpunan \& Logika Samar serta Aplikasinya. Yogyakarta : Graha Ilmu. 